\title{
THE VISA EXEMPTION POLICY IMPLEMENTATION ON GLOBAL MOBILITY: A STRATEGY TO MINIMISING THE RISKS AND MAXIMISING THE BENEFITS OF VISA POLICIES
}

\author{
Agung Sulistyo Purnomo \\ Dosen Politeknik Imigrasi \\ Jl Raya Gandul No. 4 BPSDM Hukum dan HAM \\ Kementerian Hukum dan HAM RI \\ No HP: 08157071700, email: theagungpurnomo@gmail.com
}

\begin{abstract}
To secure Indonesian borders and uphold state's sovereignty, the Directorate General of Immigration (Imigrasi) must develop an effective monitoring strategy. Managing people's mobility within the Indonesian territory should also be the main concern of the current government amidst the implementation of the visa waiver policy. This means that the economic benefit expected from the free-visa policy must not undermine the national security. In particular, this study argues that the visa exemption policy is not related to the rise of immigration violations and, therefore, the level of immigration offense is influenced by other factors including poor management and scrutiny of foreign arrivals. This paper will analyse secondary data to deeply understand what challenges faced by Imigrasi during the implementation of President Regulation No. 21 of 2016 about the visa waiver for 169 countries. The data was originally obtained through interviews, surveys, research, and reports published by academic researchers or government/nongovernment agencies. This method is utilised as a means to gather all relevant information related to the topic discussion, especially, in finding the urgency for reform and adjusting Imigrasi's policy direction. The result conveys that visa exemption regulation needs to be reviewed immediately.
\end{abstract}

Keywords: free visa, policy strategy, immigration violation, reciprocal principle.

\begin{abstract}
ABSTRAK
Untuk mengamankan perbatasan Indonesia dan menegakkan kedaulatan negara, Imigrasi harus mengembangkan strategi pemantauan yang efektif. Mengelola mobilitas orang di dalam wilayah Indonesia juga harus menjadi perhatian utama pemerintah saat ini di tengah pelaksanaan kebijakan bebas visa. Ini berarti bahwa manfaat ekonomi yang diharapkan dari kebijakan bebas visa tidak boleh mengesampingkan aspek keamanan nasional. Secara khusus, penelitian ini berpendapat bahwa kebijakan pembebasan visa tidak terkait dengan meningkatnya pelanggaran imigrasi dan, oleh karena itu, tingkat pelanggaran keimigrasian lebih dipengaruhi oleh faktor lain yaitu pengelolaan dan pengawasan orang asing yang belum maksimal. Penelitian ini akan menganalisis data sekunder untuk memahami secara mendalam tantangan yang dihadapi Imigrasi selama pelaksanaan Peraturan Presiden No. 21 tahun 2016 tentang bebas visa untuk 169 negara. Data tersebut awalnya diperoleh melalui wawancara, survei, penelitian, dan laporan yang diterbitkan oleh peneliti akademis atau instansi pemerintah/non-pemerintah. Metode ini digunakan sebagai sarana untuk mengumpulkan dan menelaah semua informasi yang relevan yang berkaitan dengan topik diskusi, terutama dalam menemukan urgensi untuk reformasi dan penyesuaian arah kebijakan Imigrasi kedepan. Hasilnya menunjukkan bahwa peraturan bebas visa perlu segera dikaji ulang.
\end{abstract}

Kata kunci: bebas visa, strategi kebijakan, pelanggaran keimigrasian, asas resiprokal. 


\section{INTRODUCTION}

These days granting free entry for foreign tourists is believed to be the key market strategy for Indonesia in promoting tourism destinations. In particular, this visa-free policy aims to boost the country's tourist arrivals. Under a governmental decision, since March 2016, Indonesia waived visa requirements for 169 countries with 30 days maximum stay period. This new visa waiver policy was driven by the urgency of stabilising the national economic condition ${ }^{1}$.

Under the economic policy package ${ }^{2}$, the government sees tourism sector as a great solution to solve the economic problem. The development of tourism sector is considered effective to boost the economic growth. However, the visa exemption policy seems to compromise the Immigration Law as it did not take into account the reciprocal principle. Along with the expected benefits of the visa waiver, it also comes with potential security risks that will affect the society. The Directorate General of Immigration Republic of Indonesia (Imigrasi) forecasts that this new visa policy will contribute to a greater social cost as a result of inequality. A massive influx of foreigners will create more problems for the local society. Unequal economic competition and skill between foreign and local residents will have a serious impact on the stability of national security.

Previously, Indonesia has waived the visa procedures for all ASEAN member states. This initiative was intended to strengthen the bond between the countries in Southeast Asia region. One of its strategies is to making ASEAN an attractive destination for foreign trade and investment. Even further, the ASEAN member states realise the potential benefit of visa waiver as an incentive for increasing the number of tourist

1 Muhammad Afdi Nizar, 'Pengaruh Jumlah Turis Dan Devisa Pariwisata Terhadap Nilai Tukar Rupiah', Jurnal Kepariwisataan

Indonesia, 7 (2012)

$<$ https://ideas.repec.org/p/pra/mprapa/65629.h tml>.

2 ' Paket Kebijakan Ekonommi', Solusi Jokowi, 2015

<http://www.kemenkeu.go.id/paketkebijakane konomi> [accessed 1 March 2017]. arrivals from non-ASEAN countries ${ }^{3}$. Hence, Indonesia among other ASEAN member states enacted the visa exemption for 169 countries for tourism purpose. This decision also followed by the establishment of the economic cooperation labeled as the ASEAN Economic Society (MEA) and the initiation of the ASEAN common visa.

The Ministry of Tourism has forecasted that this visa waiver policy will increase the tourist arrivals up to ten million people per year from eight million in $2013^{4}$. This put Indonesia on the third position of the largest tourism growth among Southeast Asia countries after Thailand and Malaysia. The UNWTO claims that tourism has become one of the largest and fastest growing economic sector in the world. In addition, an increasing number of destination and new attractions have turned tourism into the key of export revenues, job creators, enterprises, and infrastructure development. Consequently, the government, in this year stipulated a priority program for Imigrasi to support the tourism sector.

Unfortunately, the visa exemption policy has not followed by thorough preparation, especially, in immigration facilities and human resources. As a matter of fact, Imigrasi has very limited officials for monitoring purpose at immigration checkpoints across Indonesia. Other than that, Imigrasi has an urgency to upgrade its information system to ensure the high quality service on people's traffic and mobility, especially, for the huge wave of tourist arrivals. More importantly, scrutiny aspect also becomes a huge problem because of the inadequacy of facilities and infrastructure and human resources. These challenges should be addressed carefully to minimise the infringement of Immigration Law

3 World Tourism Organization, UNWTO Annual Report 2014 (Madrid, 2015) <http://dtxtq4w60xqpw.cloudfront.net/sites/all /files/pdf/unwto_annual_report_2014.pdf>.

4 Sapta Nirwandar, 'Pariwisata Indonesia Dan Masyarakat Ekonomi ASEAN' (Jakarta:

Kementerian Pariwisata dan Ekonomi Kreatif Republik Indonesia, 2015). 
and at the same time facilitating tourism sector's development plan.

As a means of strengthening the border, Imigrasi must develop an effective monitoring strategy. Managing people's mobility within the Indonesian territory should also be the main concern of the current government amidst the implementation of the visa waiver policy. This means that the economic benefit expected from the free-visa policy must not undermine the national security. This study explains how Imigrasi should strengthen its role and capacity in monitoring the massive influx of people in order to suppress potential immigration violations in Indonesia caused by the visa exemption implementation. As the nature of the visa policy involves many aspects from the society, in particular, this study argues that the visa exemption policy is not related to the rise of immigration violations and, therefore, the level of immigration offense is influenced by other factors including poor management and scrutiny of foreign arrivals.

\section{RESEARCH METHOD}

To be more comprehensive, this paper applies qualitative method. This method offers thorough understanding about the main issues within the free visa implementation and its subsequent development under the lenses of immigration principles. This study utilises secondary data derived from official hearings, internal documentations (laws and regulations) and various literatures about Imigrasi and tourism. Some examples illustrated throughout this paper are based on the author's professional experience and observation as Imigrasi's officer.

\section{FINDINGS AND DISCUSSIONS}

5 Eric Neumayer, 'Unequal Access to Foreign Spaces: How States Use Visa Restrictions to Regulate Mobility in a Globalized World', Transactions of the Institute of British Geographers, 31 (2006), 72-84
In the light of migration management system, visa is often used as a means of government's control towards unwanted travellers for getting into their area of jurisdiction. This preventive system is, then, translated into a visa policy which contains of preconditions and sanctions imposed to foreigners before crossing a territorial boundary. In a sense, this immigration policy instrument aims to protect national assets and interests and at the same time maintain national security. However, in the Indonesian visa exemption case, up to 169 countries have been authorised to visit Indonesia without visa. This decision leaves the country widely open to any traveller who attempt to enter Indonesian territory without a selection or screening processes. Indeed, this become a great concern for immigration officials who responsible to police the border.Controlling wanted and unwanted travellers is essential no only as a symbol of state's sovereignty but more importantly also to protect national security from any potential threat from the outsiders.

Several studies point out how countries employ visa restriction, while others do not. Economic and security reasons might become the main driver of a state's government to manage the complex trade-off between them in order to achieve particular interests ${ }^{5}$. Furthermore, Neumayer reveals that some OECD countries, are remain in concern on systematically keeping out foreign passport holders from their countries, while they have privilege to enjoy less restriction from poorer nations such as South East Asian Countries. OECD is a an organisation composed of the world's most advanced countries dedicated to support economic development in order to build stronger, cleaner, and fairer world ${ }^{6}$. The inequality in access to foreign spaces as previously mentioned in the work of Neumayer indicates that every state

<http://dx.doi.org/10.1111/j.14755661.2006.00194.x>.

6 OECD, 'Better Policies for Better Lives', Members and Partners, 2017

<http://www.oecd.org/about/membersandpart ners/> [accessed 2 June 2017]. 
has sovereign control on entry of inward migration and monitors its border. This also implies that every single nation, ideally, use selective policy principle which means only travellers who are beneficial and considered low threat to a country of destination that will be granted an entry permit.

To better understand about latent threats within the visa exemption program, Siskin ${ }^{7}$ as the US immigration expert points back to the $9 / 11$ events which arise the government concern about the ability of terrorists to enter the US under visa waiver program. This is not exaggerating since the program bypasses the first step of screening for admissibility of foreigners at the consular offices abroad. It was up to 13.5 million visitors in 2003 and 16.2 million visitors in 2009 entered the US under this program, which constitutes $49 \%$ and $50.5 \%$ of total overseas visitors respectively ${ }^{8}$.

In response to the national security issue, the Immigration and Nationality Act specifies that to use the facility of the US visa waiver program, a country must offer reciprocal privileges to the US citizens, have had a non-immigrant refusal rate less than $3 \%$, certify that the country will issue machine-readable passports with biometric identifiers, and not compromise the law enforcement or security interest of the US. Countries who fail to follow these guidelines will be immediately terminated from the visa waiver program ${ }^{9}$. To add more security on this program, the US government, in 2009, also implemented the Electronic Travel Authorisation System through which foreign visitors must electronically provide, in advance of travel, their biographical information for admissibility purposes ${ }^{10}$.

ASEAN community program can be a good example on how reciprocal principle works to maintain national assets and interests. The

7 Visa Waiver Program, Federal Publications (Washington DC, 2004)

<http://travel.state.gov/content/visas/en/visit/v isa-waiver-program.html>.

8 Siskin, Visa Waiver Program; Alison Siskin, Visa Waiver Program, Congressional Research Service (Washington DC, 2010) $<$ http://travel.state.gov/content/visas/en/visit/v isa-waiver-program.html $>$.
ASEAN connectivity has three main pillars of political-security, economic, and sociocultural ${ }^{11}$. These pillars are translated into visions and several strategic objectives. The visions comprise of physical, institutional, and people to people connectivity. Some of the objectives are promoting seamless logistic and people mobility among the member states, which will directly encounter Immigration regulations in the respective countries. In other words, these initiatives will need a harmonisation in visa regulations among beneficiary countries. This practice in which accommodates member states' interests is appropriate since in line with reciprocal principle just like what Schengen did for the European Union.

While the ASEAN community struggling on the realisation of ASEAN common visa as a means of strengthening regional cooperation and trade-offs, The European Union seems hesitate to continue their common visa policy program as they realise that the findings of the evaluation shows the other way around and not as previously expected. The Community Code on Visas (Visa Code) is subjected into a revision because in practice, consulates do not sufficiently distinguish between unknown applicants and known applicants who have positive visa record ${ }^{12}$. Subsequently, procedural facilitations for known applicants are rarely performed. Lastly, the existing visa procedure is considered ineffective and inefficient due to the extensive use of outsourcing which leads to the lack of discretion in services. Hence, the European Union, firstly, propose to make the most of visa information system and differentiating the treatment of known and unknown travellers based on clear and objective criteria. Secondly, they assert to further facilitate legitimate travel by streamlining

9 Siskin, Visa Waiver Program, p. 2.

10 Siskin, Visa Waiver Program.

11 The ASEAN Secretariat, Master Plan on ASEAN Connectivity, Community Relations Division (Jakarta: The ASEAN Secretariat, 2016).

12 The Comission to the European Parliament and the Council, A Smarter Visa Policy for Economic Growth (Brussels, 2014). 
procedures and by reducing certain mandatory provisions where consulates' discretion took place. The rest of the revision points highlight the importance of consular cooperation, facilitations for family members of Union citizens and easier access to Schengen visa application in as many places as possible. For these reasons, the European Union wishes to raise the number of visits to the EU with enhanced security systems. In this regards, a new article will be inserted in the Visa Code as follows,

"The purpose of this Regulation is to determine those third countries whose nationals are subject to or exempt from the visa requirement, based on a case-by-case assessment of a variety of criteria relating, inter alia, to illegal immigration, public policy and security, the economic benefits, in particular in terms of tourism and foreign trade, and the Union's external relations with relevant third countries including, in particular, human rights and fundamental freedoms considerations, as well as the implications of regional coherence and reciprocity."

The proposed article explicitly mentions about the importance of maintaining security and economic aspects at the same time by utilising the reciprocal principle as the magic wand.

Through data collection and careful analysis, the European Commission realises the need of harmonisation between innovation and security impact ${ }^{13}$. Time and simplicity of the visa process are the issue of travellers but it does not allow this to sacrificing national security. The first timer to entering the European Union still requires biometric data record. To boost tourist arrivals, the European Union will make several adjustments on their visa procedures such as: less documentary requirements, online application procedures, longer validity, and rendering the processing time. More importantly, they are not recommend the idea of visa free entry and visa on arrival even though it would be able to eliminate the abovementioned issues and related problems since it will cost them more in terms of security and legal perspective.

To be more precise, Han, Lee, $\&$ Lee ${ }^{14}$ have made a considerable effort to examine the influence of visa exemption scheme to the visit intention using the extended Theory of Planned Behaviour and Theory of Reasoned Action. They took the data from potential Chinese travellers to Korea. The result contributes to an understanding that visa exemption for Chinese travellers to Korea has a significant attraction which influences their decision-making process of selecting Korea as a tourist destination. However, further investigation should be conducted to see the actual impact of tourist visa exemption to the Chinese travellers since it has not yet become effective until now. Furthermore, the authors have gathered some evidence that visa exemption policy has contributed to the increasing numbers of tourist in Hong Kong and Japan. They recorded that a year after the implementation of visa waiver policy, Hong Kong experiencing up to 40.4 percent of tourist arrivals in 2004, while Japan 12.2 percent in 2006 and 25.0 percent in 2007. Nevertheless, the Korean's government seems to be reluctant in the idea of visa free policy, yet they still calculating the costs associated with social impact like illegal stay for employment which mainly comes from China.

\footnotetext{
14 'Extending the Theory of Planned Behavior: Visa Exemptions and the Traveller DecisionMaking Process', Tourism Geographies, 13 (2011), 45-74 $<$ http://dx.doi.org/10.1080/14616688.2010.52 9930>.
} 
Conversely, Nirwandar, $\mathrm{S}^{15}$ as a Deputy Minister for Tourism and Creative Economy Republic of Indonesia reports the urgency to the transformation of Indonesia's tourism into a world class standard. He claims that tourism sector has remarkable world-wide contribution of nine percent of GDP, one in eleven jobs, US\$ 1159 billion international tourism receipts, and uninterrupted growth up to 1087 million international tourist arrivals in 2013. In addition, the tourism sector has been proclaimed as one of the largest and fastest growing economic sector in the world. In the national scale, the contribution of the tourism sector per 2013 has reached 8.8 million international arrivals, four percent of national GDP, US\$ 10 billion receipts, 10.13 million jobs, and US\$ 603 million tourist investment. Coincided with the implementation of ASEAN integration in the form of ASEAN Economic Community (AEC) in 2016, which promotes free flow of goods and people, the Ministry of Tourism seize this opportunity by influencing the government to authorise the free visa for 169 countries. Per their prediction, tourist arrivals will increase up to 10 million per year with estimated spending each visit around US\$ 1200 per person. Interestingly, this wishful thinking has not been followed by the calculation of social and security costs.

Similarly, Nizar, M. A ${ }^{16}$ underlines the reciprocal causal relationship between (tourist numbers and receipts) and the exchange rates of Indonesian Rupiah. He sums up that the increase numbers of tourists and receipts will appreciate (increase) the exchange rates of Rupiah to US Dollar and vice versa. Furthermore, he recommends that the development program in tourism sector should be integrated with the national program of increasing foreign exchange and national exchange rate policy at the same time. The findings correlate with the visa exemption agenda promoted by the Ministry of Tourism, which can be labelled as 'open door

\footnotetext{
15 (2015)

${ }^{16}(2012)$

17 Upaya Jajaran Keimigrasian Dalam Implementasi Kebijakan Bebas Visa (Jakarta: BPSDM Hukum dan HAM, 2016).
}

policy' as it is a means to attract people as many as possible without selective procedure as mandated by the Immigration Law.

However, Paramarta, Y. A ${ }^{17}$ doubts the benefit of the free-visa implementation in Indonesia as he realises that this policy does not accommodate security and social interests. As a developing country, Indonesia needs extra protections from external threats since it still lacks of competitive human resources and technology. The threats can be in the forms of transnational crimes like human trafficking, illicit drugs, cybercrime, and massive numbers of illegal foreign workers. In the one hand, the visa exemption facilitates tourism industries and contributes to huge amounts of national receipts. On the other hand, the free visa policy also eliminates security functions of Imigrasi at immigration checkpoints. Along with this free visa implementation, Imigrasi must be equipped with adequate facilities and infrastructures to manage the foreign arrivals appropriately. This dilemma leaves the government to two possible alternatives, either amends the visa exemption law or enhance immigration surveillance to assure secure environment and at the same time support the development plan of tourism industry of Indonesia.

As an alternative, Sudarwati, $\mathrm{Y}^{18}$ sums up important points related to the visa waiver program implementation. As a critic to the new policy, she asserts the urgent needs to build and improve tourism infrastructures in targeted regions to attract international travellers. More importantly, the government also need to reinforce the legal standing related to this new policy as it apparently conflicts with the higher law in Indonesian judiciary system. In more detail, the conflicting laws will be discussed later with some possible policy alternatives and consequences. Subsequently, the government

\footnotetext{
18 'Optimalisasi Kebijakan Bebas Visa Kunjungan Singkat', Info Singkat Ekonomi Dan Kebijakan Publik, VII (2015), 4.
} 
should be able put the visa waiver implementation right on its track by involving the main stakeholders such as Imigrasi, the Ministry of Foreign Affairs, and the Ministry of Tourism in program evaluation and control to minimising the potential threats and maximising the benefit.

From the brief explanation about the visa and its use as mentioned above, it can be clearly seen how developed countries persist in maintaining their interests by utilising visa restriction to other countries. The example of OECD countries and the US in their visa system underline that albeit the unequal access in foreign spaces and disparities between the rich and the poor countries, security and economic issue might become an accepted justification globally. Conversely, Indonesia as a developing country, has waived the visa for 169 countries without considering selective policy and reciprocal principle merely to pursue economic growth generated by foreign tourism and commerce. To be more specific, the discussion around Indonesian visa exemption program and its potential benefit and drawbacks will be elaborated in the following section.

The President Regulation of the Republic of Indonesia No. 43 in 2011 about the third amendment of the Presidential Decree No. 18 in 2003 specifies 15 countries of free visa-recipients, which mostly ASEAN member states with additional non-ASEAN members such as: Morocco, Peru, Chile, Hong Kong, and Macau. These countries have the privilege to visit Indonesia without any visa and vice versa. This facility is a means of enhancing mutual relationship between the involved countries through equal access and opportunities. Nevertheless, in March 2016, the Jokowi regime enacted a visa exemption program for 169 countries to boost revenue through tourism industry. This new policy is supported by the Ministry of Tourism and Creative economy and the business community. The Minister of Tourism views the visa exemption program as an instrument to facilitate and encourage foreign visitors for business and pleasure, which contributes to the increase of national receipts from foreign tourism and commerce. However, he seems to forget to mention the risks following this new program, which have potential threat to national stability. Additionally, the visa exemption program will potentially eliminate nontax revenue derived from visa on arrival valuing up to 1.3 trillion rupiahs (equal to US\$130 million) per year.

Nevertheless, the UNWTO ${ }^{19}$ argue that visa policies are inadequate and inefficient, which hinder the growth of tourism industries. Rather than seeing visa as a security and control from a nation state to immigrants, they see visa as an obstacle, which has a cost and too many formalities. They perceive that the developing countries are now more open than the advanced ones. South-East Asian are among the most open. The emerging economy like Indonesia is suggested to fully reap the benefits international tourism can bring to economy by putting in place 'no visa regulations' so that the country can be easily visited and attract substantial investment.

However, along with the outstanding projection of economic gains from tourism sector, the visa exemption program has gone against the universal norms of immigration lawi.e. selective policy and reciprocal principle. Ignoring these two fundamental aspects will result in a greater social conflict and disparity. A case in point, Imigrasi has recorded a lot of visa misuse under this new program. The free-visa is supposed to be used as tourism or business purposes. However, there are many foreigners, especially from China, that have been working in Indonesia using the free-visa facility. Consequently, local workers feel threatened by the influx of Chinese illegal workers in the Indonesian territory. Other than that, Imigrasi has also arrested numbers of

19 'Visa Facilitation: Stimulating Economic Growth and Development through Tourism' (Madrid: UNWTO, 2013), p. 12 
foreigners who commit cyber-crime and human trafficking under the free-visa facility. From this point, the social cost caused by the foreign criminals as previously mentioned might be greater than the economic advantages, which should gain government attention and conduct immediate evaluation towards the implementation of this visa waiver program.

Other concerns related to the visa waiver implementation is that Imigrasi as the leading sector in protecting the border and national sovereignty has not yet been equipped with adequate facilities and infrastructures. Imigrasi runs by only 7000 officials across Indonesia, which divided by a Headquarter,125 regional offices, 13 detention centres, 18 representative offices abroad and 203 immigration checkpoints. With more than 250 million of Indonesian population, Imigrasi faces a huge challenge ahead. This circumstance is unlike the neighbouring countries such as Malaysia with 12000 staff and Singapore with 6000 staff, which have far less population and area than Indonesia ${ }^{20}$. In this concern, Imigrasi has a huge responsibility to secure the entire borders which scatters across the archipelago.

Saleh, J. $\mathrm{S}^{21}$ asserts the main tasks and responsibilities of Imigrasi, well known as 'Tri Fungsi Imigrasi," are public service provider, law enforcer, and national security apparatus. Understanding the standing position of Imigrasi based on its core functions towards free visa policy implementation is critical since it will lead to different findings in the evaluation of this new visa policy. The focus of this project is how to strengthen Imigrasi's role and functions in protecting the border and state sovereignty. To fulfil these tasks, Imigrasi should develop an effective security and intelligence unit. These units aim to provide secure environment for both local and international citizens. In practice, we can

\footnotetext{
${ }^{20}$ Martahan Sohuturon, 'Komisi III DPR Minta Moratorium Untuk CPNS Imigrasi Dicabut', CNN Indonesia, 2016

<http://www.cnnindonesia.com/nasional/2016 0506141629-20-128974/komisi-iii-dpr-minta-
}

see how visa and passport control works by undertaking careful analysis, screening, and profiling on documents and towards the applicants. The procedures are surely take times on its process but it now can be simplified by using information technology and creating a reliable immigration information system. Thus, any believe which considered that screening systems and procedures are just obstacles for reaping economic benefits will soon collide with the universal norms of immigration as above mentioned.

Imigrasi as the leading agency which is directly affected by the implementation of freevisa policy must take a measure towards the plan to amend the free-visa regulation. The momentum has come to bring forward the idea of strengthening the border. The hearing and evaluation plan toward the existing visa policy are a great start to, firstly, frame the problem and at the same time offer feasible solutions. As an alternative to address the visa exemption policy problem, secondly, this idea must be strengthened and backed up by prominent figures within the government. Luhut B Pandjaitan might become a potential and powerful supporter to set the government agenda and open the window of opportunity. He has diverse experience in the fields of military, diplomacy, and government. $\mathrm{He}$ is one of the first Jokowi's confidants to serve as a Head of the Presidential Staff. Then, he served as Minister of Political, Legal, and Security Coordination. He currently holds a position in the cabinet as the Minister of Maritime Coordinator of the Republic of Indonesia replacing Rizal Ramli.

Indeed, there will be more pressures from the Tourism Ministry as they have a great interest in there. However, Imigrasi must focus on manifesting the problem along with the solutions and then seek the political attention. The political will to address the issue and solutions onto a formal agenda is imperative. The prominent figure

moratorium-untuk-cpns-imigrasi-dicabut/> [accessed 2 September 2016].

${ }^{21}$ Sekuriti Dan Intelijen Keimigrasain (Jakarta:

Direktorat Jenderal Imigrasi, 2008). 
in public policy, Kingdon ${ }^{22}$ claims that once the problem, policy, and political streams are joined together, the windows of opportunity shall open widely, and that is the time for key policy entrepreneurs (Imigrasi and other supporters of border protection) to seize the opportunity and seek the reform as discussed earlier.

\section{CONCLUSION}

This paper unpacks some important issues related to the visa exemption policy, which is effective in early 2016 until present. The enactment of this policy was closely related to the program of the Minister of Tourism, which attempts to promote and boost Indonesia as a leading tourist destination in South East Asia region. Malaysia and Thailand are the main rivals which managed to lure more than 20 million foreign tourists per year, while Indonesia not more than 10 million. Rather than producing innovations and focus on the promotion and development of tourist destination and facilities, the Minister of Tourism, Arief Yahya supported by the former Coordinating Minister of Maritime, Rizal Ramli propose to waive visa requirements for 169 countries to entering Indonesia. As the proponent of this free-visa program, they projected that in 2019, Indonesia will surpass Malaysia and Thailand in tourism receipts.

\footnotetext{
${ }^{22}$ Agendas, Alternatives and Public Policies, 2nd edn (Michigan: HarperCollins College Publishers, 1995); 'A Model of AgendaSetting, with Applications', The Second Annual Quello Telecommunications Policy and Law Symposioum (Washington DC: Hein Online, 2001), pp. 331-40; 'Wrapping Things Up', in Kingdon, John W, Agendas, Alternatives, and Public Policies, 2nd edn (Boston: Longman, 2011), pp. 196-208.

${ }^{23}$ Neumayer, 'Unequal Access to Foreign Spaces: How States Use Visa Restrictions to Regulate Mobility in a Globalized World'; Eric Neumayer, 'Visa Restrictions and Bilateral Travel', Professional Geographer, 62 (2010), 171-81 <http://dx.doi.org/10.1080/003301210036008 35>; Vincent Hakyemez, The Visa System in
}

It has been argued that this policy will contribute significantly to the national foreign exchange, increase GDP, and at the same time provide thousands of jobs vacancy for Indonesian people. Other than that, the visa waiver program has been also widely advocated by the UNWTO, especially, to the developing countries. However, there is a price for this policy which escapes the Indonesian policy makers' attention. Imigrasi as the most affected government agency of this policy has been left out and excluded from the establishment of this visa-free regulation. In addition to the lack of monitoring facilities and the readiness of human resources, Imigrasi's senior officials have warned the government for the violation towards the immigration Act No. 6 of 2011 regarding the reciprocal principle.

The immigration law mandates an emphasis on the principle of selective policy in allowing foreigners to enter Indonesian territory. Besides, these norms are universal and practiced by all nation-states to protect their national interest, particularly, in the developed countries. Visa policies and systems are always influenced by economic and security factors ${ }^{23}$. The EU and the US, for example, are granting visa waiver to some countries who also benefit them. More importantly, they have a well anticipated security and control system prior to the visa waiver decision ${ }^{24}$.

\section{International Relations: Patterns of} Hierarchy, Reciprocity and Regionalization (London: CISD Yearbook of Global Studies, 2014), I; Eric Neumayer, 'The Impact of Political Violence on Tourism : Dynamic Econometric Estimation in A Cross-National Pane', Journal of Conflict Resolution, 48 (2004), 259-81.

${ }^{24}$ Siskin, Visa Waiver Program; Can Emir Mutlu, 'Insecurity Communities: Technologies of Insecurity Governance under the European Neighbourhood Policy' (University of Ottawa, Canada, 2013); Sandra Lavenex, 'Migration and the EU's New Eastern Border: Between Realism and Liberalism', Journal of European Public Policy, 8 (2001), 24-42 <http://dx.doi.org/10.1080/13501760010018313> ; Imke Kruse and Florian Trauner, 'EC Visa 
With the unique geography and demography, Indonesia should not only consider on pursuing economic benefit on tourism sector by waiving visa requirements to almost every country in the world. Indonesia should also consider the internal security aspect that currently missed out. Visa waiver program is not the only possible solution on earth to increase foreign exchange in tourism. However, to strike a balance between economic benefits and security in the free-visa policy, several alternatives can be considered as follows. Firstly, equip Imigrasi with advanced monitoring-control facilities and infrastructure. Secondly, improve the visa exemption regulation for further review of the countries which are likely to be given the ease of visa and reduce the length of stay in Indonesia, so as to be appropriate and not misused. Last but not least, increase tourist attraction and create more tourists-friendly destinations across Indonesian archipelago.

\section{REFERENCES}

Attstrom, Karin, Mathilde Heegaard Bausager, Ida Maegaard Nielsen, Jonathan Leonardsen, Troels Nybro Hansen, and Anthony Mercer, Study on the Economic Impact of Short Stay Visa Facilitation on the Tourism Industry and on the Overall Economies of EU Member States Being Part of the Schengen Area (Brussels, 2013)

Collinson, Sarah, 'Visa Requirements, Carrier Sanctions, "Safe Third Countries" and "Readmission": The Development of an Asylum 'Buffer Zone in Europe', Royal Geographical Society, 21 (1996), 76-90

Facilitation and Readmission Agreements: A New Standard EU Foreign Policy Tool?', European Journal of Migration and Law, 10 (2008), 411-38

<http://dx.doi.org/10.1163/157181608X376872>; Jef Huysmans, 'The European Union and the Securitization of Migration', Journal of Common Market Studies, 38 (2000), 751-77

<http://dx.doi.org/10.1111/1468-5965.00263>; Julius a Mollet, 'Ethical Issues in Social Science Research in Developing Countries : Useful or Symbolic', 2005, 1-9; Virginie Guiraudon, 'European Integration and Migration Policy: Vertical Policy-Making as Venue Shopping',
Guiraudon, Virginie, 'European Integration and Migration Policy: Vertical Policy-Making as Venue Shopping', Journal of Common Market Studies, 38 (2000), 251-71 $<$ http://dx.doi.org/10.1111/14685965.00219> , 'The Constitution of a European Immigration Policy Domain: A Political Sociology Approach', Journal of European Public Policy, 10 (2003), 263-82 <http://dx.doi.org/10.1080/1350176032000 059035>

Hakyemez, Vincent, The Visa System in International Relations: Patterns of Hierarchy, Reciprocity and Regionalization (London: CISD Yearbook of Global Studies, 2014), I

Han, Heesup, Sungil Lee, and Choong-Ki Lee, 'Extending the Theory of Planned Behavior: Visa Exemptions and the Traveller DecisionMaking Process', Tourism Geographies, 13 (2011), 45-74 <http://dx.doi.org/10.1080/14616688.2010. 529930>

Huysmans, Jef, 'The European Union and the Securitization of Migration', Journal of Common Market Studies, 38 (2000), 751-77 $<\mathrm{http} / / / \mathrm{dx}$.doi.org/10.1111/14685965.00263>

Kementerian Keuangan Republik Indonesia, 'Paket Kebijakan Ekonommi', Solusi Jokowi, 2015 <http://www.kemenkeu.go.id/paketkebijaka

Journal of Common Market Studies, 38 (2000), 251-71<http://dx.doi.org/10.1111/14685965.00219>; Virginie Guiraudon, 'The Constitution of a European Immigration Policy Domain: A Political Sociology Approach', Journal of European Public Policy, 10 (2003), 263-82

<http://dx.doi.org/10.1080/135017603200005903 5>; Sarah Collinson, 'Visa Requirements, Carrier Sanctions, "Safe Third Countries" and "Readmission": The Development of an Asylum 'Buffer Zone in Europe', Royal Geographical Society, 21 (1996), 76-90. 
nekonomi> [accessed 1 March 2017]

Kingdon, John W, 'A Model of Agenda-Setting, with Applications', The Second Annual Quello Telecommunications Policy and Law Symposioum (Washington DC: Hein Online, 2001), pp. 331-40

-, Agendas, Alternatives and Public Policies, 2nd edn (Michigan: HarperCollins College Publishers, 1995)

, 'Wrapping Things Up', in Kingdon, John

$W$, Agendas, Alternatives, and Public Policies, 2nd edn (Boston: Longman, 2011), pp. 196-208

Kruse, Imke, and Florian Trauner, 'EC Visa Facilitation and Readmission Agreements: A New Standard EU Foreign Policy Tool?', European Journal of Migration and Law, 10 (2008),

411-38 <http://dx.doi.org/10.1163/157181608X376 872>

Lavenex, Sandra, 'Migration and the EU's New Eastern Border: Between Realism and Liberalism', Journal of European Public Policy, $\quad 8 \quad$ (2001), $\quad 24-42$ $<$ http://dx.doi.org/10.1080/1350176001001 8313>

Mollet, Julius a, 'Ethical Issues in Social Science Research in Developing Countries: Useful or Symbolic', 2005, 1-9

Mutlu, Can Emir, 'Insecurity Communities: Technologies of Insecurity Governance under the European Neighbourhood Policy' (University of Ottawa, Canada, 2013)

Neumayer, Eric, 'The Impact of Political Violence on Tourism: Dynamic Econometric Estimation in A Cross-National Pane', Journal of Conflict Resolution, 48 (2004), 259-81

-, 'Unequal Access to Foreign Spaces: How States Use Visa Restrictions to Regulate Mobility in a Globalized World', Transactions of the Institute of British Geographers, $31 \quad$ (2006), 72-84 $<$ http://dx.doi.org/10.1111/j.1475- 5661.2006.00194.x>

, 'Visa Restrictions and Bilateral Travel', Professional Geographer, 62 (2010), 17181

$<$ http://dx.doi.org/10.1080/0033012100360 0835>

Nirwandar, Sapta, 'Pariwisata Indonesia Dan Masyarakat Ekonomi ASEAN' (Jakarta: Kementerian Pariwisata dan Ekonomi Kreatif Republik Indonesia, 2015)

Nizar, Muhammad Afdi, 'Pengaruh Jumlah Turis Dan Devisa Pariwisata Terhadap Nilai Tukar Rupiah', Jurnal Kepariwisataan Indonesia, 7

$<$ https://ideas.repec.org/p/pra/mprapa/65629 .html>

OECD, 'Better Policies for Better Lives', Members and Partners, 2017 $<$ http://www.oecd.org/about/membersandpa rtners/> [accessed 2 June 2017]

Paramarta, Y Ambeg, Upaya Jajaran Keimigrasian Dalam Implementasi Kebijakan Bebas Visa (Jakarta: BPSDM Hukum dan HAM, 2016)

Saleh, John Sarodja, Sekuriti Dan Intelijen Keimigrasain (Jakarta: Direktorat Jenderal Imigrasi, 2008)

Siskin, Alison, Visa Waiver Program, Federal Publications (Washington DC, 2004) $<$ http://travel.state.gov/content/visas/en/visit /visa-waiver-program.html>

, Visa Waiver Program, Congressional Research Service (Washington DC, 2010) $<$ http://travel.state.gov/content/visas/en/visit /visa-waiver-program.html>

Sohuturon, Martahan, 'Komisi III DPR Minta Moratorium Untuk CPNS Imigrasi Dicabut', CNN Indonesia, 2016 <http://www.cnnindonesia.com/nasional/20 160506141629-20-128974/komisi-iii-dprminta-moratorium-untuk-cpns-imigrasidicabut/> [accessed 2 September 2016]

Sudarwati, Yuni, 'Optimalisasi Kebijakan Bebas Visa Kunjungan Singkat', Info Singkat 
Ekonomi Dan Kebijakan Publik, VII (2015),

4

The ASEAN Secretariat, Master Plan on ASEAN

Connectivity, Community Relations Division

(Jakarta: The ASEAN Secretariat, 2016)

The Comission to the European Parliament and the Council, A Smarter Visa Policy for Economic Growth (Brussels, 2014)

UNWTO, 'Visa Facilitation: Stimulating Economic Growth and Development through Tourism' (Madrid: UNWTO, 2013), p. 12

World Tourism Organization, UNWTO Annual Report $2014 \quad$ (Madrid, 2015) <http://dtxtq4w60xqpw.cloudfront.net/sites/ all/files/pdf/unwto_annual_report_2014.pdf 